\title{
Farmers Perception of the Quality and Accessibility of Agrochemicals in Kaduna and Ondo States of Nigeria: Implications for Policy \\ Http://dx.doi.org/10.4314/jae.v20i1.7
}

\author{
Issa, F. $\mathbf{O}$. \\ Department of Agricultural Extension and Economics, \\ National Agricultural Extension and Research Liaison Services, \\ Ahmadu Bello University, Zaria \\ Corresponding: issafola@gmail.com,+2348033339312
}

\begin{abstract}
This study analyzed the quality and accessibility of agrochemicals as perceived by crop farmers in Kaduna and Ondo States of Nigeria. A total of 260 crop farmers were selected for the study using multi-stage sampling procedure. Data were collected using pre-tested, structured interview schedule. Descriptive statistics and multiple regression were used for data analysis. Findings revealed that the majority (62.7\%) of the crop farmers perceived the quality of agrochemical to be poor or just average. Similarly, many (43.5\%) perceived agrochemical as accessible. Farmers' perception of quality of agrochemical was strongly influenced by level of education (0.059) and experience (0.015) among others. On the other hand, perception of accessibility of agrochemical is influenced by education (0.064) and income (0.012) among others. Major constraints to accessing quality agrochemicals were inadequate enforcement of pesticide regulations, high cost, and porous borders. This study therefore, recommends that government should device policy and special financial incentive (subsidy) geared towards boosting local production of agrochemical. It is also advocated that government should review pesticide laws to facilitate the effective supervision of pesticide quality in Nigeria.
\end{abstract}

Key words: Agrochemical, farmers' perception, agricultural inputs

\section{Introduction}

Traditionally, Nigerian farmers have been relying heavily on pesticides for the control of various weeds, insect pests and diseases, leading to the high importation of these products. The prices have become so high that it is becoming impossible for local farmers to afford (Schwab, Jager, Stoll, Gorgen, Prexterschwab, and Attenburger, 1995) since most of them are engaged in smallholder semi-subsistence agriculture (Ajibolade, 2005). The source of pesticides used by the farmers includes agrochemicals retailers, input traders, and Agricultural Development Programme (ADP) (Mokwunye, Babalola, Ndagi, Idrisu, Mokwunye, and Asogwa, 2012). A survey by Nigerian Institute of Social and Economic Research (NISER), (1999) on the 
Creative commons User License: CC BY-NC-ND

Abstracted by: EBSCOhost, Electronic Journals Service (EJS),

Google Scholar, Directory of Open Access Journals (DOAJ),

Journal Seek, Scientific Commons,

Food and Agricultural Organization (FAO), andCABI
Journal of Agricultural Extension

Vol. 20 (1) June, 2016

ISSN(e): 24086851; ISSN(Print); 1119944X

http://journal.aesonnigeria.org

http://www.ajol.info/index.php/iae

Email: editorinchief@aesonnigeria.org

strategies used by agribusiness firms suggests that the use of buying agents and direct purchase from the open market are quite popular amongst agribusiness firms. It has been estimated that about 125,000 - 130,000 metric tons of pesticides are applied every year in Nigeria (Asogwa and Dongo, 2009). However, it is not certain if the pesticides are of desired good quality. Pesticides have been introduced into the Nigerian farming system ever since they were used in the industrialized world. The mandate to screen and recommend potential crop pesticides lies with the designated research institutes. However, the effect of the new European Union Legislation on Maximum Residue Levels (MRLs) since the regulation came into effect since Sept 1, 2006 is yet to be substantially ascertained. Chemicals are essential requirements of modern society that need to be managed properly in order to achieve a sustainable level of agricultural and industrial development, and a high level of environmental and human health protection.

Pesticide registration is a scientifically-based, legal, and also administrative process, where a wide variety of effects associated with the use of a pesticide product and its potential effect on human health and the environment is assessed (Monaco, Weller and Ashton, 2002; Commission of the European Communities (CEC), 1991; Environmental Protection Agency (EPA), 2009). The registration is an important step in the management of pesticides as it enables authorities primarily to determine which pesticide products are permitted to be used and for what purposes, and also to exercise control over quality, usage rates, claims, labelling, packaging and advertising of pesticides, thus ensuring that the best interest of end-users as well as the environment are well protected (World Health Organization (WHO), 2010).

The major types of chemicals used in Nigeria are imported majorly from European and Asian countries. There are only few companies in the country that formulate and package agrochemicals such as gammalin 20 (Lindane) and Butachlor, insecticides, rodenticides, etc. The active ingredients of these formulations are however imported. Some formulations are however undertaken, often without adequate consideration for human health and the environment during their handling, storage, use and disposal. Although national legislative instruments and policies are in place; implementation and enforcement are inadequate due to limited national infrastructure and capacity to manage chemicals. At the international level, considerable attention has been given to the sound management of chemicals. Since the late 1980s, several international policy instruments have been adopted; the most recent being the adoption of the strategic approach to international chemicals management (SAICM) by the International Conference on Chemicals Management (ICCM) in Dubai United Arab Emirates, February 2006. Through the SAICM, Nigeria was identified as one of the pilot countries with the aim of establishing key baseline data on quality of national chemicals and waste (Anyadiegwa, 2007). Also, the $60^{\text {th }}$ ordinary session of ECOWAS Council of Ministers held at Abuja on 17 and 18 May 2008 adopted the harmonized rules governing pesticide agreement in the ECOWAS zone. A major aim of this common regulation is to facilitate an appropriate and timely access by farmers to quality pesticides. An estimated $30 \mathrm{MT}$ of agrochemical is wasted per annum (Akunyili and Ivbijaro, 2006; NAFDAC, 1996). 
Creative commons User License: CC BY-NC-ND

Abstracted by: EBSCOhost, Electronic Journals Service (EJS),

Google Scholar, Directory of Open Access Journals (DOAJ),

Journal Seek, Scientific Commons,

Food and Agricultural Organization (FAO), andCABI
Journal of Agricultural Extension

Vol. 20 (1) June, 2016

ISSN(e): 24086851; ISSN(Print); 1119944X

http://journal.aesonnigeria.org

http://www.ajol.info/index.php/iae

Email: editorinchief@aesonnigeria.org

Despite the fact that many pesticides have been banned in Nigeria (Ezie, 2008), it is not clear that some of these products are completely absent in the Nigerian markets. The porous nature of Nigerian border as well as numerous illegal borders worsens the situation. A banned pesticide is that, for which all registered use have been prohibited by final government regulation action or for which all request for registration or equivalent action for all uses, have for health or environmental uses not been granted. The Nigeria Committee on PIC (Prior Informed Consent) procedure usually takes final decision on pesticides to be banned in the country and their decision is informed by actions taken under the Rotterdam Convention for International control of pesticides and other hazardous chemicals.

Kaduna and Ondo States have markedly different agro-ecological condition. This difference could make crop protection practices (as well as the type of agrochemicals used) to vary substantially in the two states. However, both states are noted for heavy use of agrochemicals. According to the annual national agricultural performance survey of wet seasons in Nigeria carried out by the National Agricultural Extension and Research Liaison Services (NAERLS), quantities of agrochemical procured by the two states and distributed to farmers for use between 2008 and 2014 indicated that an estimated 143,330 liters was used in Kaduna State while 308,053 liters was used in Ondo State. Agrochemical supplying companies operating in Ondo State include Saro Agro Science, FITSCO Nigeria Limited, INSIS Nigeria Limited, and Dizengoff African Agro. Jubaili, Saro and Dizengoff were the major sources of agrochemical in Kaduna State.

Different companies produce pesticides that contain the same active ingredient, which are sold under several trade names. The active ingredient (abbreviated as a.i.) is the compound that is used to control the harmful organism. Its ability to kill, harm or deter a certain pest or disease has been proven and its use for this purpose is authorized through a registration process. Pesticides used in Nigeria include certain chemicals that, for environmental reasons, have been partially or completely banned in developed countries, but for which effective cheap substitutes have yet to be evolved. Such chemicals continue to find their way into Nigeria for pest control (Akinyosoye, 2005).

Perception in this study is defines as the ways by which farmers conceive agrochemical to be of good quality and accessible. Quality is an essential and distinguishing attributes of a particular agrochemical. The quality of any agrochemical is determined by its efficiency to control, repel, or destroy pests of any sort: weed, insects and fungi. Quality is a characteristic property that defines the apparent individual nature of any particular agrochemical. Consumers' perception of quality is influenced by the product's intrinsic attributes as well as by extrinsic indicators and cues provided by the seller of the product (Caswell, 1998). Christos, Damalas and Ilias (2014) asserts that pesticide quality is associated with increased cost. Dongmei (2006) reports that the education and training provided by agricultural extension personnel affect farmers' awareness of pesticide quality. Kaduna and Ondo States where this study had been carried out were the largest consumer of agrochemicals in Nigeria (National Agricultural Extension and Research Liaison Services and National Programme on Agriculture and Food Security (NAERLS and NPAFS), 2011). 
Creative commons User License: CC BY-NC-ND

Abstracted by: EBSCOhost, Electronic Journals Service (EJS),

Google Scholar, Directory of Open Access Journals (DOAJ),

Journal Seek, Scientific Commons,

Food and Agricultural Organization (FAO), andCABI
Journal of Agricultural Extension

Vol. 20 (1) June, 2016

ISSN(e): 24086851; ISSN(Print); 1119944X

http://journal.aesonnigeria.org

http://www.ajol.info/index.php/iae

Email: editorinchief@aesonnigeria.org

Farmers can have the availability of large quantity of agrochemicals promptly in comparison to other places. Also, many private shops sell agrochemicals by which the farmers have easy access. This has encouraged the individuals to depend on chemicals instead of other means of controlling pests.

Accessibility of agrochemical is a quality of being at hand when needed. It is the degree of convenience to which specific agrochemical can be obtained by farmer for use. Akingboye, Fadipe, Adigun and Animashaun (2014) analysed accessibility of agrochemicals based on sources. They found that agrochemicals gotten from personal savings were very accessible, while accessibility of agrochemicals from other sources (such as government, development agencies, ADPs and farmers' cooperatives) was poor (i.e. not accessible at all).

The most dominant problem plaguing agricultural production in Nigeria is input delivery and support services. Nigerian farmers had not obtained the modern farm inputs on time and in good qualities and had always paid high prices (Onasanya, 2007; Otujinrin, 1997). The advent of modern technologies in agricultural production has also brought about tremendous production of various substandard inputs resulting in sub-optimal yields and environmental hazards/pollution (Agoro, 2007). Quality Input (agrochemical inclusive) remains a major factor that can enhance the performance of enterprises in Nigeria (Manyong, Ikpi, Olayemi, Yusuf, Omonona, Okoruwa and Idachaba, 2005; International Fertilizer Development Centre (IFDC), 2001) but unfortunately, Nigerian input distribution has been characterized by inefficiencies and abuses (Akinyosoye, 2005).

\section{Purpose of the Study}

The purpose of this study was to analyse farmers' perception of quality and accessibility of agrochemicals in Nigeria. Specifically, the study identified the sources of agrochemicals and crop farmers' perception of their quality and accessibility; identified the types of agrochemicals commonly used by farmers; identified the time of acquisition of agrochemicals by crop farmers, determined the socio-economic factors influencing farmers' perception of quality and accessibility of agrochemicals; and identified the constraints to access quality agrochemicals.

\section{Methodology}

This study was carried out in Kaduna and Ondo States from the Northern and Southern Nigeria, respectively. Kaduna State lies between longitude $06^{\prime} 00$ and $09^{\prime} 10^{\prime}$ East of the Greenwich Meridian between and latitudes $09^{\circ} 00$ and $11^{0} 30$ north of the Equator. Kaduna State occupies an area of approximately 48,473.2 square kilometres (Federal Office of Statistics (FOS), 2006). Kaduna State has 23 Local Government Areas and its population was put at 6, 066, 526 people (National population Commission [NPC], 2006) and had a projected population of 7, 813, 685 people in 2015 using an annual growth rate of 3.2\%. Ondo State was created on 3 February 1976 from the former Western State. It originally included what is now Ekiti State, which was split off in 1996 . Ondo State lies between latitudes $5^{\circ} 45^{\prime}$ and $7^{\circ} 52^{\prime} \mathrm{N}$ and longitudes $4^{\circ} 20^{\prime}$ and $6^{\circ} 05^{\prime} \mathrm{E}$. Its land area is about 15,500 square kilometres. 
Creative commons User License: CC BY-NC-ND

Abstracted by: EBSCOhost, Electronic Journals Service (EJS),

Google Scholar, Directory of Open Access Journals (DOAJ),

Journal Seek, Scientific Commons,

Food and Agricultural Organization (FAO), andCABI
Journal of Agricultural Extension

Vol. 20 (1) June, 2016

ISSN(e): 24086851; ISSN(Print); 1119944X

http://journal.aesonnigeria.org

http://www.ajol.info/index.php/iae

Email: editorinchief@aesonnigeria.org

Ondo State has 18 Local Government Areas and its population was put at 3, 460, 877 people (NPC, 2006) and had a projected population of 4, 457, 609 people in 2015 using an annual growth rate of $3.2 \%$. A wide range of fungicides are available in Ondo State (Olabode, Adesina, and Olapeju, 2011) due to heavy use of fungicides associated with cocoa production.

This study focused on crop farmers who had been using agrochemicals for at least five years in Kaduna and Ondo States of Nigeria. The selection of these states was based on high volume of use of agrochemical as reported by NAERLS and NPAFS (2011). A multi-stage sampling technique was employed in selecting the farmers. Stages one and two were purposive selections of two agricultural zones of ADPs per state; and 2 blocks per zone, respectively. The criterion for the purposive selections was the intensity of agrochemical use based on the record of the ADPs. The third stage involved the purposive selection of two villages per block. Lastly, the fourth stage involved using the list of farmers obtained from the reconnaissance survey (conducted by the researcher between $2^{\text {nd }}$ and $9^{\text {th }}$ September, 2013) to randomly select $15 \%$ of farmers from each of the eight villages. In all, a total of 135 and 125 crop farmers were selected from Kaduna and Ondo State, respectively and a total of 260 crop farmers.

Data for the study were collected with the use of pre-tested, structured interview schedule administered on the farmers. Farmers were visited to conduct on-the-spot interview. Data collection exercise was conducted between $26^{\text {th }}$ August and $29^{\text {th }}$ September, 2014. Trained enumerators were used for data collection.

Multiple regression technique was used to estimate the relationship between farmers' socio-economic characteristics and their perception of quality and accessibility of agrochemicals. Multiple regression was determined using:

$Y 1=a_{0}+b_{1} x_{1}+b_{2} x_{2}+b_{3} x_{3} \ldots \ldots \ldots \ldots \ldots \ldots \ldots \ldots \ldots b_{9} x_{9}+e$

$Y 2=a_{0}+b_{1} x_{1}+b_{2} x_{2}+b_{3} x_{3}$

$b_{9} x_{9}+e$

Where:

$Y_{1}=$ Farmers' perception of quality \{perception, High (4), Average (3), Poor (2), Very poor (1)\}

$\mathrm{Y}_{2}=$ Farmers' perception of accessibility \{perception, High (4), accessible (3), Poorly (2), Not

accessible (1)\}

$\mathrm{X}_{1}=$ Age (Actual age of farmers in years)

$\mathrm{X}_{2}=\operatorname{Sex}$ (male or female)

$\mathrm{X}_{3}=$ Farm Size (size of farm in hectares)

$\mathrm{X}_{4}=$ Years of formal education (years)

$X_{5}=$ Years of farming experience (number of years in farming)

$\mathrm{X}_{6}=$ Income (total income in naira per anum)

$\mathrm{X}_{7}=$ Household size (number of persons in household)

$\mathrm{X}_{8}=$ Social participation (number of association participated in and membership status)

$\mathrm{X}_{9}=$ Cosmopoliteness (number of times travelled out of village for agricultural purpose).

It was hypothesized that there was no significant relationship between farmers' socioeconomic characteristics and their perception of quality, and accessibility of agrochemicals. 


\section{Results and Discussion}

\section{Sources of Agrochemicals, and Crop Farmers' Perception of their Quality and Accessibility}

Table 1 presents the result of crop farmers' sources, quality, and accessibility of agrochemicals. The majority (52.6 and 50.4\%) of the crop farmers in Ondo and Kaduna State, respectively patronized the input traders. Analysis showed that $34.6 \%$, and $32.3 \%$ bought pesticides from agro-service centres and open market respectively. Only $5.0 \%$ bought pesticides from licensed vendors and the others bought from vendors they knew but not sure about the license. This result confirms the findings of Mokwunye et al. (2012) that the source of pesticides used by the farmers includes agrochemicals retailers, traders, and Agricultural Development Programmes (ADPs). 
Table 1: Distribution of crop farmers based on sources, perception of quality, and accessibility of agrochemicals

\begin{tabular}{|c|c|c|c|}
\hline Variables & Kaduna (n=135) & Ondo $(n=125)$ & Both $(n=260)$ \\
\hline \multicolumn{4}{|c|}{ Sources of agrochemical* } \\
\hline Agro-service center & $38(28.1)$ & $52(41.6)$ & $90(34.6)$ \\
\hline Input traders & $71(52.6)$ & $63(50.4)$ & $134(51.5)$ \\
\hline Research Institute & $2(1.5)$ & $2(1.6)$ & $4(1.5)$ \\
\hline Open market & $45(33.3)$ & $39(31.2)$ & $84(32.3)$ \\
\hline Licensed vendor & $5(3.7)$ & $8(6.4)$ & $13(5.0)$ \\
\hline \multicolumn{4}{|l|}{ Distance (Km) } \\
\hline$<20$ & 70 (51.9) & $61(48.8)$ & $131(50.4)$ \\
\hline $21-40$ & $30(22.2)$ & $23(18.4)$ & $53(20.4)$ \\
\hline $41-60$ & $10(7.4)$ & $7(5.6)$ & $17(6.5)$ \\
\hline $61-80$ & $7(5.2)$ & $14(11.2)$ & $21(8.1)$ \\
\hline $81-100$ & $14(10.4)$ & $12(9.6)$ & $26(10.0)$ \\
\hline Above 100 & $4(2.9)$ & $8(6.4)$ & $12(4.6)$ \\
\hline \multicolumn{4}{|c|}{ Perception of quality of agrochemical } \\
\hline High & $53(39.3)$ & $44(35.2)$ & $97(37.3)$ \\
\hline Average & $64(47.4)$ & $69(55.2)$ & $133(51.2)$ \\
\hline Poor & $15(11.1)$ & $11(8.8)$ & $26(10.0)$ \\
\hline Very poor & $3(2.2)$ & $1(0.8)$ & $4(1.5)$ \\
\hline \multicolumn{4}{|c|}{ Perception of accessibility of agrochemical } \\
\hline Highly accessible & $4(2.9)$ & $15(12.0)$ & $19(7.3)$ \\
\hline Accessible & $70(51.8)$ & $61(51.2)$ & $131(50.3)$ \\
\hline Poorly accessible & $54(40.0)$ & $41(32.8)$ & $95(36.5)$ \\
\hline Not accessible & $7(5.2)$ & $8(6.4)$ & $15(5.8)$ \\
\hline \multicolumn{4}{|c|}{ Perception of timeliness } \\
\hline Timely & $92(68.1)$ & $87(69.6)$ & $179(68.8)$ \\
\hline Not timely & $43(31.8)$ & $38(30.4)$ & $81(31.2)$ \\
\hline
\end{tabular}

*Multiple responses indicated

Figures in parentheses are percentages

With respect to distance to source of agrochemical, though most (50.4\%) of the crop farmers travelled less than 20 Kilometres to purchase agrochemical, $49.6 \%$ of them travelled over 20 kilometres to buy agrochemicals. There is no doubt that farmers located far away from reputable source might found it easier to patronize sources (pesticide sellers) which are not reputable. The negative consequence of this is that farmers might have been exposed to fake, adulterated and obsolete pesticides with further resultant effects of agrochemical failure. Closeness to reputable sources of agrochemical would enhance the adoption of recommended practices relating to the use of genuine products as declared by Amsalu and De Graaff (2006). Furthermore, most $(51.2 \%)$ of the crop farmers perceived the quality of agrochemicals to be just average. In fact, $11.5 \%$ perceived the quality to be poor; or very poor. Two reasons can be adduced for this finding. The first one is that farmers might have used fake or adulterated chemicals in the past. The other reason might be that such farmers might have misuse the chemical due to lack of training. Above all, many (43.8\%) of the crop farmers declared their dissatisfaction with the quality of agrochemicals. This finding corroborates that of NAERLS and NPAFS (2013) who lamented the prevalence of fake and adulterated pesticides in the Nigerian market. 
Creative commons User License: CC BY-NC-ND

Abstracted by: EBSCOhost, Electronic Journals Service (EJS), Google Scholar, Directory of Open Access Journals (DOAJ), Journal Seek, Scientific Commons,

Food and Agricultural Organization (FAO), andCABI
Journal of Agricultural Extension Vol. 20 (1) June, 2016

ISSN(e): 24086851; ISSN(Print); 1119944X http://journal.aesonnigeria.org http://www.ajol.info/index.php/iae Email: editorinchief@aesonnigeria.org

Many $(42.3 \%)$ of the farmers perceived the accessibility of agrochemical as poor or not accessible. The majority (57.7\%) of the crop farmers who perceived accessibility of agrochemical as accessible or highly accessible might have been those who are closer to the urban areas where agrochemicals are easily found. The truth, however, is that farmers who need agrochemicals abound more in the rural areas. This underscores the need for agrochemical sales to be visible in the rural areas.

\section{Types of Agrochemicals used by Crop Farmers}

Pesticides commonly used by crop farmers are presented in Table 2. Glyphosate, paraquat, and atraxine were found as mostly used herbicides by the majority $(88.8 \%$, $73.5 \%$, and $65 \%$ respectively) of the crop farmers. For insecticides, chlopyrifos and cypermethrin were the most used as indicated by the majority $(60.8 \%$, and $56.2 \%$, respectively). Metalaxyl-M was the mostly used fungicide as indicated by $61.1 \%$ of the crop farmers. Amera and Abate (2008), Keri (2009), and Tekwa, Ambali, and Gabdo,(2010) found similar result. The high consumption of fungicide in Ondo State could not be unconnected with the prevalence of fungi attack on cocoa, the production of which the state is noted for. Different pesticides are used for different products (crops) depending on the problem and situation.

Table 2: Types of agrochemicals used by crop farmers

\begin{tabular}{lllll}
\hline Pesticide Group & Types of agrochemicals used & Kaduna (n=135) & Ondo (n=125) & Both (n=260) \\
\hline Herbicides & 2-4-D & $15(11.1)$ & $17(13.6)$ & $32(12.3)$ \\
& Paraquat & $96(71.1)$ & $95(76.0)$ & $191(73.5)$ \\
& Glyphosate & $119(88.1)$ & $112(89.6)$ & $231(88.8)$ \\
& Atraxine & $88(65.2)$ & $81(64.8)$ & $169(65.0)$ \\
& Atraxine + Metolachlor & $69(51.1)$ & $63(50.4)$ & $132(50.8)$ \\
& Butachlor & $47(34.8)$ & $42(33.6)$ & $89(34.2)$ \\
& Carbufuran & $33(24.4)$ & $28(22.4)$ & $61(23.5)$ \\
& Chlorpyrifos & $77(57.0)$ & $81(64.8)$ & $158(60.8)$ \\
& Aluminium phosphide & $9(6.7)$ & $12(9.6)$ & $21(8.1)$ \\
& Cypermethrin & $77(57.0)$ & $69(55.2)$ & $146(56.2)$ \\
& Cypermethrin+Dimethoate & $23(17.0)$ & $11(8.8)$ & $34(13.1)$ \\
& Dichlorvos & $74(54.8)$ & $65(52.0)$ & $139(53.5)$ \\
& Dimethoate & $40(29.6)$ & $20(16.0)$ & $6(2.3)$ \\
& Imidachloprid & $13(9.6)$ & $10(8.0)$ & $23(8.8)$ \\
& Lambda-cyhalothrin+Dimethoate & $8(5.9)$ & $7(5.6)$ & $15(5.8)$ \\
& Metalaxyl-M & $37(27.4)$ & $102(81.6)$ & $159(61.1)$ \\
& Carbendazim & $28(20.7)$ & $91(72.8)$ & $129(49.6)$ \\
& Copper hydroxide & $19(14.1)$ & $105(84.0)$ & $124(47.7)$ \\
& Copper hydroxide + Metalaxyl-M & $9(6.7)$ & $64(51.2)$ & $73(28.1)$ \\
& Mancozeb & $19(14.1)$ & $54(43.2)$ & $75(28.8)$ \\
& Mancozeb + carbendazim & $7(5.2)$ & $31(24.8)$ & $38(14.6)$ \\
\hline
\end{tabular}

*Multiple responses

Figures in parenthesis are percentages

Time of acquisition of agrochemical by crop farmers 
Creative commons User License: CC BY-NC-ND

Abstracted by: EBSCOhost, Electronic Journals Service (EJS),

Google Scholar, Directory of Open Access Journals (DOAJ),

Journal Seek, Scientific Commons,

Food and Agricultural Organization (FAO), andCABI
Journal of Agricultural Extension

Vol. 20 (1) June, 2016

ISSN(e): 24086851; ISSN(Print); 1119944X

http://journal.aesonnigeria.org

http://www.ajol.info/index.php/jae

Email: editorinchief@aesonnigeria.org

The majority (52.8\%) of the crop farmers in Ondo preferred to buy agrochemicals when the need arose, while farmers in Kaduna State (50.1\%) preferred to buy at the beginning of cropping season (Table 3).

Table 3: Distribution of crop farmers based on the time of the year when crop farmers acquire agrochemical

\begin{tabular}{llll}
\hline Time crop farmers acquire agrochemical & Kaduna $(n=135)$ & Ondo $(n=125)$ Both $(n=260)$ \\
\hline Beginning of the cropping season & $73(50.1)$ & $34(27.2)$ & $107(41.2)$ \\
Ending of cropping season & $0(0)$ & $16(12.8)$ & $16(6.2)$ \\
When the need arises & $58(42.9)$ & $66(52.8)$ & $124(47.7)$ \\
When it is available for sale & $4(2.9)$ & $9(7.2)$ & $13(5.0)$ \\
\hline
\end{tabular}

Figures in parenthesis are percentages

Influence of Farmers' Socio-economic Characteristics on their Perception of Quality and Accessibility of Agrochemicals

The result of multiple regression on the influence of socio-economic characteristics on farmers' perception of the quality and accessibility of agrochemicals is presented in Table 4. The adjusted $R^{2}$ was 0.65 , and 0.68 for quality and accessibility, respectively. This implies that $63 \%$ of the variations in the perception of quality were contributed by the independent variables specified in the model, while $67 \%$ of the variations in the perception of accessibility was contributed by the independent variables specified in the model. This shows that the variables fit the model. It was hypothesized that there is no significant relationship between farmers' socioeconomic characteristics and their perception of quality and accessibility of agrochemicals. However, some variables were found to significantly influence farmers' perception of quality, as well as accessibility of agrochemicals. Age (0.023), level of education (0.059), farming experience (0.015), social participation (0.807) and cosmopoliteness $(0.063)$ were found to significantly influence farmers' perception of quality. For perception of accessibility, the variables were education (0.064), level of income (0.012), social participation (0.301), and cosmopoliteness (0.005). These variables were strong determinants of farmers' perception of quality and accessibility of agrochemicals. Therefore, contrary to the stated null hypothesis; farmers' socioeconomic characteristics significantly influenced quality and accessibility of agrochemicals. Hence, the null hypothesis was rejected.

A strongly positive and significant relationship was found between crop farmers' educational level and perception of quality and accessibility (0.059) and (0.064), respectively. This implies that a unit increase in the educational level of the farmer will bring about $5 \%$ and $6 \%$ increase in farmers' perception of quality and accessibility, respectively. In other words, farmers with higher education had more favourable perception of quality and accessibility of agrochemicals, a result consistent with the findings of Yasin, Aslam, Parvez, and Naz, (2003). The perception of quality and accessibility given high literacy is $58 \%$ and $65 \%$, respectively, making this factor the greatest driver of perception of quality and accessibility of agrochemicals by crop farmers. Education creates a favourable mental attitude for assessing the quality of a product. Education affords a person the ability to read and 
Creative commons User License: CC BY-NC-ND

Abstracted by: EBSCOhost, Electronic Journals Service (EJS), Google Scholar, Directory of Open Access Journals (DOAJ), Journal Seek, Scientific Commons,

Food and Agricultural Organization (FAO), andCABI
Journal of Agricultural Extension Vol. 20 (1) June, 2016

ISSN(e): 24086851; ISSN(Print); 1119944X http://journal.aesonnigeria.org

http://www.ajol.info/index.php/iae Email: editorinchief@aesonnigeria.org

understand sophisticated information that may be contained in a package thereby increasing perception of quality. Farmers' exposure to education increases their ability to obtain, process and utilize information relevant to accessing new technologies (Bonabana-Wabbi, 2002).

Furthermore, a positive and significant relationship was found between years of farming experience and farmers' perception of quality (0.015). However, experience is not related to accessibility. The mean number of years that farmers had been using agrochemicals was 24.7. The general indication is that individuals with more experience in using agrochemicals would likely understand the quality perhaps reflecting their experience. Ani (1998) and Iheanacho (2000) also indicated that farming experience to a large extent affects farmers' managerial know-how. Namwata, Lwelamira, and Mzirai,(2010) reported that increased farming experience was positively and significantly associated with overall adoption of improved agricultural technologies among farmers in Tanzania. However, on the contrary, Adesope, Matthews-Njoku, Oguzor, and Ugwuja, (2012) found an inverse relationship between adoption and farming experience which means that those with less farming experience have higher adoption level. Experience of the farmer is likely to have a range of influences on their perception. Experience will improve farmers' skill at production. A more experienced farmer may have a lower level of uncertainty about the innovation's performance. Farmers with higher experience appear to have often full information and better knowledge and are able to evaluate the advantage of the technology considered. Therefore, it was found that farming experience has a positive influence on perception of accessibility of technologies (Okuthe, Kioli, and Abuom, 2013; Bello, Ibrahim, Salau, Kaura, and Age, 2010).

Farmers' sex, farm size, and household size had no significant coefficient in the model for both perceptions of quality and accessibility. It is important to discuss the implications of this result. Contrary to previous studies suggesting gendered patterns in adoption due to women's limited access to resources including land and credit (Tonye, 1997; Adesina, Mbila, Nkamleu, and Endamana,2000) the results suggest no significant difference between male and female farmers in terms of perception of quality and accessibility of agrochemicals. However, this result is similar to that of Doss and Morris (2001) who observed that the adoption of maize varieties and fertilizer is not associated with the sex of maize farmers in Ghana. This may be due to increased efforts by government policy as well as development agents in widening opportunities for hitherto vulnerable groups especially women.

Social participation had significant relationship with farmers' perception of quality of agrochemicals (0.807). Iwueke (1987) also found out that social participation was one of the variables that positively related to the farmers' perception about new practices and that this could be predicted on the basis by peer-group's decisions.

Table 4: Influence of farmers' socio-economic characteristics on their perception of quality and accessibility of agrochemicals in Kaduna and Ondo States

Variables 
Creative commons User License: CC BY-NC-ND

Abstracted by: EBSCOhost, Electronic Journals Service (EJS), Google Scholar, Directory of Open Access Journals (DOAJ), Journal Seek, Scientific Commons,

Food and Agricultural Organization (FAO), andCABI
Journal of Agricultural Extension

Vol. 20 (1) June, 2016

ISSN(e): 24086851; ISSN(Print); 1119944X

http://journal.aesonnigeria.org

http://www.ajol.info/index.php/jae

Email: editorinchief@aesonnigeria.org

\begin{tabular}{lllllll} 
& Coef. & Std. Err & Z & Coef. & Std. Err & Z \\
\hline Age & 0.023 & 0.013 & $2.14^{*}$ & 0.0003 & 0.003 & 0.13 \\
Gender & 0.004 & 0.073 & 0.06 & 0.004 & 0.072 & 0.05 \\
Farm size & 0.005 & 0.006 & -0.87 & 0.004 & 0.006 & -0.86 \\
Education & 0.059 & 0.004 & $5.54^{*}$ & 0.064 & 0.004 & $4.18^{*}$ \\
Farming exp. & 0.015 & 0.007 & $2.16^{*}$ & 0.033 & 0.016 & 0.43 \\
Income & 0.103 & 0.914 & 0.59 & 0.012 & 0.006 & $2.06^{*}$ \\
Household size & -0.013 & 0.004 & -3.88 & -0.008 & 0.003 & $-3.23^{*}$ \\
Social participation & 0.807 & 0.479 & $1.68^{*}$ & 0.301 & 0.502 & $4.56^{*}$ \\
Cosmopoliteness & 0.063 & 0.027 & $2.33^{*}$ & 0.005 & 0.003 & $2.16^{*}$ \\
$\mathrm{R}^{2}$ & 0.670 & & & 0.697 & & \\
Adjusted R & 0.653 & & & 0.684 & & \\
${ }^{*} \mathrm{P} \leq 0.05$ & & & & & & \\
\hline
\end{tabular}

\section{Farmers' Constraints to Access and Quality of Agrochemicals}

Result in Table 5 indicates that inadequate enforcement of pesticide regulations ranked highest among the constraints as indicate by $85 \%$ of the respondents. Enforcement of pesticide regulation is important to prevent banned pesticides and adulterated ones in circulation. Akinyosoye (2005) asserted that banned chemicals usually find their ways into Nigeria.

Table 5: Farmers' constraints to access and quality of agrochemicals

\begin{tabular}{lll}
\hline Constraints to access and quality of agrochemicals & Percent & Rank \\
\hline Inadequate enforcement of pesticide regulations & 85.0 & $1^{\text {st }}$ \\
High cost of agrochemicals & 76.2 & $2^{\text {nd }}$ \\
Porous borders & 66.5 & $3^{\text {rd }}$ \\
Illiteracy & 54.6 & $4^{\text {th }}$ \\
Poor farming experience & 38.8 & $5^{\text {th }}$ \\
Unavailability of pesticides & 37.7 & $6^{\text {th }}$ \\
\hline
\end{tabular}

\section{Conclusion and Recommendations}

Crop farmers perceived the quality of agrochemical to be poor or just average. Similarly, many perceived agrochemical as accessible. Age, education, farming experience, social participation and cosmopoliteness were the major factors influencing farmers' perception of quality of agrochemicals; while education, income, social participation and cosmopoliteness were the major determinants of accessibility of agrochemicals. Inadequate enforcement of pesticide regulations, high cost, and porous borders were the major constraints to access quality agrochemicals in Nigeria. 
Creative commons User License: CC BY-NC-ND

Abstracted by: EBSCOhost, Electronic Journals Service (EJS),

Google Scholar, Directory of Open Access Journals (DOAJ),

Journal Seek, Scientific Commons,

Food and Agricultural Organization (FAO), andCABI
Journal of Agricultural Extension

Vol. 20 (1) June, 2016

ISSN(e): 24086851; ISSN(Print); 1119944X

http://journal.aesonnigeria.org

http://www.ajol.info/index.php/jae

Email: editorinchief@aesonnigeria.org

This paper strongly advocates that government should create special fund geared towards boosting local production of agrochemical. This can be achieved by establishing production plants in strategic locations that will enhance efficient distribution to farmers all over the country. It is also advocated that government should review pesticide laws to facilitate effective supervision of pesticide quality in Nigeria.

\section{References}

Adesina, A.A., Mbila, C., Nkamleu, G.B. and Endamana, D. (2000). Analysis of the determinants of adoption of alley farming by farmers in the forest zone of Southwest Cameroon. Agriculture, Ecosystems \& Environment, 80: 255-265.

Adesope, O. M., Matthews-Njoku, E.C., Oguzor, N.S. and Ugwuja, V.C. (2012). Effect of socio-economic characteristics of farmers on their adoption of organic farming practices, Crop Production Technologies, In Peeyush Sharma (Ed.), InTech, pp 211 - 220. Available at: http://www.intechopen.com/books/cropproduction-technologies/effect. Assessed 26/11/2012.

Agoro, A. O. (2007). Quality Control of Agricultural Inputs and its Impact on Agricultural Extension in Lagos State, Paper presented at the Pre-Season Training for Technical and Extension Officers of LSADA, $6^{\text {th }}$ March, P4.

Ajibolade, E.O. (2005). Effects of land acquisition for large scale farming on the productivity of small-scale farming in Okitipupa LGA, Ondo State. Unpublished MSc Thesis, Department of Agricultural Economics and Extension, Federal University of Technology, Akure.

Akingboye, A. E., Fadipe, A. A., Adigun, S. O. and Animashaun, J. O. (2014) Assessment of Rural Farming Households WTP forFertilizers and Agrochemicals in Kwara State, Nigeria. International Journal of Agricultural Management and Development (IJAMAD), 4(2): 163-170.

Akinyosoye, V. O. (2005). Government and agriculture in Nigeria: Analysis of policies, programmes and administration. Macmillan Nigeria Publishers Limited, Lagos. Pp598.

Akunyili, D., Ivbijaro, M.F.A. (2006). Pesticide regulations and their implementation in Nigeria. In; Ivbijaro, M.F.A.; F. Akintola and R.U. Okechukwu (eds).

Sustainable Environmental Management in Nigeria.Mattivi Production Ibadan. pp. 187-210.

Amera, T. and Abate, A. (2008). An assessment of the pesticide use, practice and hazards in the Ethiopian Rift Valley. Africa Stockpiles Programme, Annex 6. Pp 61.

Amsalu, A., and De Graaff, J. (2006). Determinants of adoption and continued use of stone terraces for soil and water conservation in an Ethiopian Highland Watershed. Journal of Ecological Economics, 61(2-3): 294-30.

Ani, A.O., (1998). Assessment of farmers' extension education needs in Yobe State, Nigeria. Nigerian Journal of Agricultural Education, 1: 152-158.

Anyadiegwa, A. (2007). Baseline study towards non-toxic environment in Africa, country report NIGERIA 19 September 2007. 
Asogwa, E.U. and Dango, L.N. (2009). Problems associated with pesticide usage and application in Nigerian cocoa production: A review. African Journal of Agricultural Research Vol. 4 (8), pp. 675-683, August. Retrieved from http://www.academicjournals.org/AJAR Assessed: 13/04/2012.

Bello, M., Ibrahim, H.I., Salau, E.S., Kaura, A.G. and Age, A.I. (2010). Factors influencing the adoption of agro-chemical technology by small-scale farmers in Kwali Area Council of Abuja FCT, Nigeria. Journal of Environmental Issues and Agriculture in Developing Countries, 2(1), April. Pp 176- 190.

Bonabana-Wabbi, J. (2002). Assessing factors affecting adoption of agricultural technologies: The case of Integrated Pest Management (IPM) in Kumi District, Eastern Uganda. MSc (Agricultural and Applied Economics) Thesis submitted to the faculty of the Virginia Polytechnic Institute and State University. $146 \mathrm{pp}$.

Caswell, J. A. (1998). Valuing the Benefits and Costs of Improved Food Safety and Nutrition. Australian Journal of Agriculture and Resource Economics, 42 (December): 409-474.

Christos, A., Damalas, I. and Ilias, G. E. (2014). Pesticide Exposure, Safety Issues, and Risk Assessment Indicators. Int. J. Environ. Res. Public Health 2011, 8, 1402-1419; doi:10.3390/ijerph8051402.

Commission of the European Communities (1991). Council Directive 91/414/EEC of 15 July 1991 Concerning the Placing of Plant Protection Products on the Market; Official Journal L 230; Commission of the European Communities: Brussels, Belgium.

Dongmei, Z. (2006). Development of bio-pesticide industry in China. PhD thesis, Fujian University of Agriculture and Forestry, Fujian, China.

Doss, C.R. and Morris, M.L, (2001). How does gender affect the adoption of agricultural Innovations? The Case of Improved Maize Technology in Ghana. Journal of Agricultural Economics, 25: 27-39.

Environmental Protection Agency (EPA) (2009). Registering Pesticides. Available online: http://www.epa.gov/pesticides/regulating/ re-gistering/index.htm (accessed on 1 April 2011).

Iheanacho, A.C., (2000). Economics of Millet production under different cropping systems in Borno State of Nigeria. Unpublished Ph.D. Thesis, University of Maiduguri, Nigeria.

International Fertilizer Development Centre (IFDC) (2001). Agricultural Input Markets in Nigeria: An Assessment and a Strategy for Development, IFDC, Aladama, USA.

Iwueke, C.C. (1987). Farmer related factors influencing the Adoption of Agricultural Innovations in Imo State. Unpublished Ph. D Thesis, Dept. of Agricultural Extension UNN, Nigeria.

Keri, H. J. (2009). Nigeria's status on pesticide registration and maximum residue levels. The workshop on pesticide Maximum Residue Levels (MRLs) held in Alexandria, Egypt. 30th March to 2nd April.

Manyong, V.M., A. Ikpi; J.K. Olayemi; S.A. Yusuf; B.T. Omonona; V. Okoruwa; \& F.S. Idachaba (2005). Agriculture in Nigeria: Identifying opportunities for increased commercialization and investment. IITA, Ibadan, Nigeria. 159p. 


\section{Journal of Agricultural Extension Vol. 20 (1) June, 2016 \\ ISSN(e): 24086851; ISSN(Print); 1119944X http://journal.aesonnigeria.org http://www.ajol.info/index.php/jae Email: editorinchief@aesonnigeria.org}

Mokwunye, I.U., Babalola, F.D., Ndagi, I., Idrisu, M., Mokwunye, F.C., and Asogwa, E.U. (2012). Farmers' compliance with the use of approved cocoa pesticides in cocoa producing States of Nigeria. Journal of Agriculture and Social Research (JASR), 12(2): Pp $44-60$.

Monaco, J.T.; Weller, S.C.; Ashton, F.M. (2002). Herbicide registration and environmental impact. In Weed Science: Principles and Practices, 4th ed.; Monaco, T.J., Weller, S.C., Ashton, F.M., Eds.; John Wiley \&Sons: New York, NY, USA.

Namwata, B.M.L., Lwelamira, J. and Mzirai, O.B. (2010). Adoption of improved agricultural technologies for Irish potatoes (Solanum tuberosum) among farmers in Mbeya Rural district, Tanzania: A case of llungu ward. Journal of Animal \& Plant Sciences, 8(1): 927- 935.

National Agricultural Extension and Research Liaison Services and National Programme on Agriculture and Food Security (2011). National report of Agricultural performance survey of 2010 wet season in Nigeria. December.175 pp.

National Agricultural Extension and Research Liaison Services and Federal Department of Agricultural Extension (2014). Agricultural performance survey of 2014 wet season in Nigeria, Executive summary. October. Pp 23.

National Population Commission (2006). Census Report of Nigeria. Population and Development Review, 33(1) (Mar., 2007), pp. 206-210 Published by: Population Council Article Stable URL: http://www.jstor.org/stable/25434601 Assessed 7th May 2013.

Nigerian Institute of Social and Economic Research (NISER) (1999). A Characterization of industrial demand for major agricultural commodities in Nigeria, Ajakaiye D.O. and Akande S.O. (eds) Nigerian Institute of Social and Economic Research, Ibadan, Nigeria.

Okuthe, I.K., Kioli, F. and Abuom, P. (2013). Socio cultural determinants of the adoption of integrated natural resource management technologies by small scale farmers in Ndhiwa Division, Kenya Current Research Journal of Social Sciences. 5(6): 203-218.

Olabode, O.S., Adesina, G.O. and Olapeju, T.R. (2011).Survey of agricultural chemicals available to farmers in South Western Nigeria. International Journal of Agricultural Economics and Rural Development, 4 (1):12 - 18.

Onasanya, S. O. (2007). Keynote address delivered at the Opening ceremony of the Pre-Season Training for Technical and Extension Officers of LSADA, $6^{\text {th }}$ March, Pp 4.

Otujinrin, F. O. (1997). Analysis of Linkage Mechanisms for Input Delivery to Farmers in Lagos State, Unpublished PGD Thesis, Ogun State University, Ago-Iwoye, P 57.

Schwab, A.I., Jager, I., Stoll, G., Gorgen, R., Prexterschwab, S., and Attenburger, R. (1995). Pesticide in tropical agriculture: Hazards and alternatives. PAN ACTA TropicalAgroecology. No. 131. 
Creative commons User License: CC BY-NC-ND

Abstracted by: EBSCOhost, Electronic Journals Service (EJS),

Google Scholar, Directory of Open Access Journals (DOAJ),

Journal Seek, Scientific Commons,

Food and Agricultural Organization (FAO), andCABI
Journal of Agricultural Extension

Vol. 20 (1) June, 2016

ISSN(e): 24086851; ISSN(Print); 1119944X

http://journal.aesonnigeria.org

http://www.ajol.info/index.php/iae

Email: editorinchief@aesonnigeria.org

Tekwa, I. J., Ambali, O. Y. and Gabdo, B. H. (2010). Economic analysis of farm hazards associated with the use of agrochemicals on agricultural farms. Australian Journal of Agricultural Engineering 1(1):7 - 13.

World Health Organization (WHO) (2010). International Code of Conduct on the Distribution and Use of Pesticides: Guidelines for the Registration of Pesticides; World Health Organization: Rome, Italy.

Yasin, G., Aslam, M., Parvez, I. and Naz, S. (2003). Socio-economic correlates of pesticide usage: The case of citrus farmers. Journal of Research (Science), Bahauddin Zakariya University, Multan, Pakistan, 14(1), June, pp. 43-48. 